\title{
Erratum to: Pro-Poor Business Law? On MKURABITA and the Legal Empowerment of Tanzania's Street Vendors
}

\section{Michal Lyons ${ }^{1} \cdot$ Alison Brown ${ }^{1}$}

\section{Erratum to: Hague J Rule Law DOI $10.1017 / \mathrm{S} 1876404512001030$}

The article was co-authored by Alison Brown. It should be cited as follows:

Lyons M, Brown A (2013) Pro-poor business law? On MKURABITA and the legal empowerment of Tanzania's street vendors. Hague J Rule Law 5(1):74-95.

We sincerely apologize for this oversight.

Ronald Janse,

$\mathrm{EiC}$, on behalf of the Editorial Board of the Hague Journal on the Rule of Law

The online version of the original article can be found under doi:10.1017/S1876404512001030.

$\triangle$ Michal Lyons

1 London, UK 